Н.Н. Аблажей *

Депортации из СССР периода Большого Террора

DOI: $10.31518 / 2618-9100-2019-1-8$

УДК 94(47)-1937/1938

Выходные данные для цитирования:

Аблажей Н.Н. Депортации из СССР периода Большого Террора // Исторический курьер. 2019. № 1 (3). Статья 8. URL: http://istkurier.ru/data/2019/ ISTKURIER-2019-1-08.pdf
N.N. Ablazhey*

\section{Deportations from the USSR during the Period of the Great Terror}

\author{
DOI: $10.31518 / 2618-9100-2019-1-8$
}

How to cite:

Ablazhey N.N. Deportations from the USSR during the Period of the Great Terror // Historical Courier, 2019, \# 1 (3). Article 8. [Available online:] http://istkurier.ru/data/2019/ISTKURIER-2019-1-08.pdf

Abstract: The article is devoted to the analysis of deportation practices in the USSR during the period of the Great Terror. A study of the departmental paper work of the NKVD and the materials of extrajudicial instances leads to the conclusion that during these years such kind of punishment as deportation from the country was widely used against foreigners. Deportations were implemented in two formats: through directives of the authorities and through out-of-court system. Some deportations of 1937-1938 represented independent repressive campaigns that coincided with the so-called "national" operations, others became their integral part. Deportations from the USSR as a type of punishment were used in the course of implementation of several "national" operations conducted by the NKVD of the USSR. The largest numbers of those deported out of the country gave the "Iranian", "German" and "Harbin"operations. In 1937-1938, the most massive evictions took place among Iranian and Chinese nationals. As many as 346713 people became the victims of the "national" operations of the NKVD, of whom 9212 foreigners were accused of espionage and expelled from the country.

Keywords: Great Terror; "national" operations; foreigners; deportations from the USSR.

The article has been received by the editor on 30.11.2018.

Full text of the article in Russian and references in English are available below.

Аннотация: Статья посвящена анализу советских депортационных практик периода Большого террора. Изучение ведомственного делопроизводства НКВД и материалов внесудебных инстанций позволило сделать вывод, что в эти годы широко использовался такой вид наказания как депортация из страны иностранцев. Депортация реализовывались в двух форматах: через директивы власти и внесудебную систему. Некоторые выселения 1937-1938 гг. были самостоятельными репрессивными кампаниями, совпавшими по времени с так называемыми национальными операциями, другие стали их составной частью. Депортации из СССР как вид наказания применялись при реализации нескольких «национальных» операций, проведенных НКВД СССР. Наибольшее количество высланных за пределы страны дали «иранская», «немецкая» и «харбинская», в результате в этом период самые массовые выселения прошли среди иранских и китайских подданных. Жертвами «национальных» операций НКВД стали 346713 чел., из которых 9212 иностранцев были обвинены в шпионаже и высланы из страны.

Ключевые слова: Большой террор; «национальные» операции; иностранцы; депортации из CCCP.

* Аблажей Наталья Николаевна, д-р ист. наук, старший научный сотрудник Института истории СО РАН (Новосибирск. Россия); доцент кафедры отечественной истории Гуманитарного института Новосибирского государственного университета, e-mail: ablazhey@academ.org

Ablazhey Natalia Nikolaevna, Doctor of Sciences (History), Senior Researcher, Institute of History, Siberian Branch of the Russian Academy of Sciences (Novosibirsk, Russia); Associate Professor, Institute of Humanities, Novosibirsk State University, e-mail: ablazhey@academ.org 
Практика высылки иностранцев в Советской России была опробована еще в 1918 г., а в 1921 г., с принятием Совнаркомом соответствующего декрета ${ }^{1}$, высылка иностранцев стала элементом советского законодательства. Уже тогда ВЧК получила, наряду с судами, право на высылку из страны по политическим мотивам не только иностранцев, но и лиц, не получивших советских видов на жительство. Одновременно советская власть реанимировала существовавшую в Российской империи практику административной высылки и право на ее применение получила утвержденная ВЦИК в мае 1922 г. внесудебная инстанция - Особое совещание (OCO) при Коллегии ГПУ (позже известное как Особое совещание при Коллегии ОГПУ (другие названия - Особое Совещание при НКВД СССР и Особое Совещание при МГБ СССР). После принятия 10 августа 1922 г. правительственного декрета «высылка за пределы РСФСР», т. е. заграницу, наряду с высылкой внутри страны, стала формой наказания. Карательный и репрессивный характер административной высылки был прописан как законодательно - положениями УК РСФСР, введенного в 1922 г. и измененного в 1926 г. (и соответствующими положениями УК союзных республик), так и ведомственными инструкциями.

Изначально высылка за границу была объединена с принудительными переселениями внутри страны, что давало широкие возможности ОГПУ-НКВД для ее применения. Обозначенный срок наказания в три года уже в марте 1924 г. был увеличен до пяти лет. Этот временной интервал распространялся как на внутреннюю ссылку, так и на «высылку за пределы государственной границы Союза ССР». Высылка применялась как в отношении советских граждан, так и иностранцев, квалифицируемых карательными органами как социально- или общественно-опасные. После создания НКВД в Положении об Особом совещании от 28 октября 1934 г. за этой инстанцией было подтверждено право административной высылки за границу. Постановление ЦИК и СНК СССР об ОСО от 5 ноября 1935 г. внесло в Положение ряд изменений, согласно которым высылка за пределы СССР распространялась только на иностранных подданных. Для советских граждан этот вид наказания был отменен. 8 апреля 1937 г. Политбюро ЦК ВКП(б), утвердив новое положение об Особом совещании, предоставило ему право осуждать к ссылке или заключению на срок от пяти до восьми лет. Что касается административной высылки, то право ОСО «высылать за пределы СССР иностранных подданных, являющихся общественно-опасными» ${ }^{2}$, было подтверждено в очередной раз.

В СССР такая категория населения как иностранцы (иноподданные) была представлена разными группами. Наиболее значительную долю в ней составляли бывшие подданные Германской, Австро-Венгерской, Османской и Персидской империй, массово въезжавшие в Российскую империю на постоянное жительство еще до революции, а также военнопленные и беженцы Первой мировой войны. В первой половине 1920-х гг. росту численности иностранцев в стране способствовали массовая трудовая иммиграция, политическая эмиграция и существовавшие возможности подтвердить иностранное гражданство через действующие в стране иностранные консульские учреждения. Второй паспорт можно было приобрести и нелегально.

Несмотря на быстрое формирование института советского гражданства, граждансконациональный статус перемещенного населения оказался не отрегулирован. В стране имелась значительная группа лиц - как не натурализовавшихся, так и не имевших прямых доказательств иностранного статуса, т. е. «бесподданных», по сути апатридов - лиц без гражданства. Несмотря на то, что общая политика советской власти в области натурализации

\footnotetext{
${ }^{1}$ Собрание Узаконений. 1921. № 62. Ст. 451.

2 Лубянка. Сталин и Главное управление госбезопасности НКВД. Архив Сталина. Документы высших органов партийной и государственной власти. 1937-1938. М.: МФД, 2004. С. 126-127 (Со ссылкой на: РГАСПИ. Ф. 17. ОП. 3. Д. 986. Л. 4, 24).
} 
в первые годы была достаточно открытой, существовали значительные ограничения, поэтому массовой натурализации иностранцев и апатридов в СССР не произошло.

Политика в области натурализации довольно быстро стала прерогативой центральной власти. Местные власти потеряли возможность проводить натурализацию уже в 1918 г. Декрет ВЦИК от 22 августа 1921 г. давал право отказывать в натурализации тем, кого власть сочтет «нежелательными». Таким образом, усиливалась роль фактора лояльности и по существу отменялся институт «двойного гражданства»3. Союзная Конституция 1924 г. приравнивала лиц, не подтвердивших статус иностранца, к советским гражданам. Согласно Постановлению ЦИК и СНК СССР от 3 сентября 1926 г. и инструкциям НКВД, к советским гражданам следовало относить всех, кто не получил видов на жительство. Проживающие в СССР иностранцы оказались фактически разделены на две большие категории: имевшие право на постоянное жительство в СССР, т. е. пробывшие в стране больше полутора лет и занимающиеся законной деятельностью, и временно пребывающих в стране, т. е. всех остальные $^{4}$. Уже к началу 1930-х гг. в СССР прекратили выдачу видов на жительство лицам, не имевших национальных паспортов, но заявлявших о принадлежности к иностранному государству. В нормативной практике в отношении таких лиц стал использоваться термин «иноподданные» или «бывшие иноподданные». Отличие данной категории населения от иностранцев определялось тем, что виды на жительство в СССР им не выдавались - по причине просроченных или отсутствующих национальных паспортов. Конституция 1936 г., а позднее и Закон о гражданстве от 19 августа 1938 г. четко отделяли граждан СССР от иностранцев и лиц без гражданства. К последним были отнесены все те, кто проживал на территории СССР, но не обладал советским гражданством, а также не имел доказательств принадлежности к иностранному государству. Институт гражданства определил границу между «своими» и «чужими», т. е. собственно гражданами и не-гражданами.

Вопрос о численности иностранцев в СССР сложный и дискуссионный, прежде всего в силу отсутствия статистики и спорности критериев отнесения к иностранцам и бывшим иноподданным. Попытки введения учета иностранцев в Советской России относятся уже к 1919 г., хотя первое статистическое обследование было проведено только в 1926 г. Учет иностранцев и их паспортизация, прежде всего выдача видов на жительство, которые, собственно, и обусловливали статус иностранца в советской России (а затем и в СССР), оказался в ведении ОГПУ. В 1935 г. паспортно-визовые функции от ОГПУ перешли к милиции, во всех регионах СССР появились отделы, отделения и группы виз и регистрации иностранцев (ОВиР). Контроль за ОВиР возлагался на 3-й отдел НКВД.

По сведениям Отдела виз и регистраций Главного управления милиции, на начало 1937 г. в СССР имелось 99 тыс. иностранных граждан ${ }^{5}$. Среди иностранцев доминировали постоянно проживавшие в стране представители иранской, греческой, польской, китайской, корейской и иных диаспор. Учет иностранцев (перебежчиков, политэмигрантов, бывших военнопленных, оптантов и других) определялся в циркуляре НКВД от 22 августа 1937 г. «Об иностранцах». В нем утверждалось, что «подавляющее количество иностранцев, живущих в СССР, является организующим началом шпионажа и диверсии», поэтому предписывалось «безусловно» прекратить продление видов на жительство гражданам 21 страны (Германии, Польши, Японии и др.); еще 10 стран - «при наличии компрометирующих материалов». Вводя ограничения при выдаче видов на жительство, одновременно предлагалось выдавать иностранцам выездные визы, тем самым стимулируя их к выезду из страны.

3 Лор Э. Российское гражданство: от империи к Советскому Союзу / Пер. с англ. М. Семиколенных. M.: Новое литературное обозрение, 2017. (Серия HISTORYA ROSSICA). C. 272.

${ }^{4}$ C3 СССР. 1926. № 59. СТ. 439.

5 Журавлев С.В. Иностранцы в Советской России в 1920-1930-е гг.: источники и методы социальноисторического исследования : автореф. дис. ... д-ра ист. наук. М., 2000; Охотин Н., Рогинский А. Из истории «немецкой операции» НКВД 1937-1938 гг. // Наказанный народ. Репрессии против российских немцев. М.: «Звенья», 1999. С. 71. 
Сложившаяся нормативно-правовая практика в области гражданства давала значительные возможности расширительного толкования национально-гражданского, a, соответственно, и правового статуса, что создавало возможности дискриминации данной категории населения. Депортации иностранцев из СССР менее известны, чем резонансные выселения советских граждан. Высылку за границу подданных некоторых государств стали широко практиковать с начала 1930-х гг., в частности, волну выселений спровоцировала паспортизация 1933 г. К практике массовых высылок иностранцев в СССР вернулись в конце 1936 г. и завершили их к концу 1939 г. Пик подобных выселений пришелся на 1937-1938 гг. Депортации иностранцев из страны шли параллельно с внутренними принудительными переселениями. В 1936-1939 гг. в СССР в отношении этнических групп, отнесенных властью к «инонациональностям» и «инородным этническим элементам», была проведена серия отселения от границы. Они массово затронули как бывших иноподданных, так и иностранцев.

В период Большого террора «иноподданные» и «бесподданные» стали жертвами репрессий, массовый характер которых обеспечили так называемые национальные операции НКВД. За период с июля 1937 г. по ноябрь 1938 гг. НКВД СССР провел целую серию таких карательных акций. Вопрос об их количестве до сих пор спорен. Последние по времени исследования в этой области, основанные на отчетном делопроизводстве НКВД и материалах внесудебных инстанций, позволяют утверждать, что в годы Большого террора в масштабах страны было реализовано 11 «национальных» операций, а именно: «польская», «немецкая», «харбинская», «латышская», «греческая», «афганская», «иранская», «эстонская», «финская», «румынская» и «смешанная». Кроме того, НКВД СССР активизировал репрессии против нелегальных мигрантов (перебежчиков) и иностранных дипломатических представителей.

Изучение ведомственного делопроизводства НКВД и материалов внесудебных инстанций позволяет утверждать, что в годы Большого террора в отношении иностранцев довольно широко применялся такой вид наказания как депортация из страны. Выселения иностранцев из СССР реализовывались в двух форматах: через директивы власти и внесудебную систему. С одной стороны, подобные операции были самостоятельными репрессивными кампаниями, совпавшими по времени с «национальными» операциями или проведенными накануне и после их завершения, с другой, они стали их составной частью. Далеко не всех иностранцев, высланных в 1937-1938 гг. из страны, НКВД учитывал как репрессированных по «национальным» операциям. Именно это обстоятельство создает дополнительные сложности при изучении депортаций иностранцев периода Большого террора и оценке численности высланных из страны.

Депортации из СССР как вид наказания применялись при реализации нескольких «национальных» операций НКВД. Первой стартовала «немецкая» операция, которая реализовывалась дольше всех. Основанием к ее проведению стал приказ НКВД № 00439 от 25 июля 1937 г., а завершилась она, как и все последующие «национальные» акции, только в середине ноября 1938 г. Согласно итоговой статистике НКВД, в ходе «немецкой» операции репрессировали 56747 человек, из которых 541 человека выслали за границу ${ }^{6}$. Согласно протоколам Комиссии НКВД и Прокурора СССР (т.н. двойки), количество немцев, высланных за границу, также составило 541 человек ${ }^{7}$. Сразу следует отметить, что итоговая статистика по высланным чаще всего не совпадает с количеством лиц, на которых имеются протоколы Комиссии. Объяснить это можно тем обстоятельством, что часть протоколов была аннулирована (о чем будет сказано ниже). Что касается общих данных о количестве репрессированных в ходе той или иной «национальной» операции, то учитывать надо и то

\footnotetext{
${ }^{6}$ ЦА ФСБ. Ф. 3. ОП. 5. Д. 1528. Л. 329.

7 Архив УФСБ по Омской области. Ф. 6. (Протоколы Комиссии НКВД и Прокурора СССР по приказу № 00439).
} 
обстоятельство, что в итоговой статистике НКВД суммированы данные не только двойки, но и Особых троек.

Пик депортаций германских подданных за пределы СССР, проведенных по «немецкой» операции, относится к сентябрю 1937 - январю 1938 г., т. е. еще к первой волне репрессий. Лидерами в высылках по «немецкой» линии оказались Украинская ССР (203 чел.), Ленинградская (99 чел.), Московская (93 чел.), Свердловская (40 чел.) и Горьковская (34 чел.) области ${ }^{8}$. НКВД АССР немцев Поволжья списки немцев, которых планировалось выслать за границу, не подавал. Отметим, что подданных Германии репрессировали не только по «немецкой», но и по другим «национальным» операциям. По данным посольства Германии, из СССР было «выдворено» 622 человека 9 , что существенно больше, чем следует из статистики НКВД. Объяснить это можно тем, что депортация из страны применялась и до, и после массовых операций. Новая волна массовых высылок из СССР немецких коммунистов-политэмигрантов пришлась на конец 1939 г., что связано с подписанием Пакта о ненападении с Германией.

На примере осужденных к высылке из СССР наглядно видно, как меняется подача материалов для слушания дел на Особое совещание с началом массовых «национальных» операций. В отношении лица, арестованного до начала той или иной «национальной» операции, даже если рассмотрение дела и попадало на период ее проведения, при подаче материалов на ОСО сохранялась традиционная форма подачи. В сопроводительных материалах указывались отдел ГУГБ, докладчик по делу, номер следственного дела, персональные данные на арестованного, «окрас» (состав преступления), когда и кем арестован и где содержится. В отношении же лиц, проходящих по «национальным» операциям, материалы к заседанию представлялись в формате «альбомной» справки. Этот принципиально новый в практике НКВД процессуальный порядок осуждения - «альбомный» - собственно, и отличает дела на лиц, проведенных через Комиссию НКВД и Прокурора СССР. Такой порядок оформления дел вводился оперативным приказом НКВД СССР № 00485 от 11 августа 1937 г. («польский» приказ) и распространялся на все «национальные» операции. Оформление дел и их рассмотрение предлагалось производить в порядке пункта 6 приказа НКВД № 00485, то есть разделять арестованных на две категории и представлять дела в «альбомном» формате. Рассмотрение производилось заочно, на основании справок, сшитых в «альбомы». «Альбомный» порядок осуждения был отменен решением Политбюро ЦК ВКП(б) от 15 сентября 1938 г., далее - приказом НКВД № 00606 от 17 сентября 1938 года ${ }^{10}$. Дела на лиц, ранее поступавших на Комиссию и ОСО, стали рассматривать Особые тройки, которые права на высылку из страны не имели. Особое совещание завершило рассмотрение всех дел по «национальным» операциям к 1 октября 1938 г.

Для наглядности приведем дело германского подданного Эбегарта Оттовича Манна, 1892 г.р. Он был арестован 29 июля 1937 г. в Узбекистане, что не помешало спецорганам предъявить ему обвинение в сборе «сведений о состоянии рудников от Челябинска до Свердловска и на Украине». Дело Манна в Комиссию не поступало. Решение по данному делу - «выслать за пределы СССР» - было приняло Особым совещанием и датировано 28 января 1938 года ${ }^{11}$. Все это время арестованный содержался во внутренней тюрьме НКВД в Ташкенте. Эти обстоятельства дают нам основание не учитывать Э.О. Манна как жертву «немецкой» операции НКВД, как и все аналогичные случаи, потому что документы не оформлены в формате «альбомной» справки и, следовательно, подследственные не проходили через Комиссию НКВД и Прокурора СССР (двойку).

\footnotetext{
${ }^{8}$ Архив УФСБ по Омской области. Ф. 6. (Протоколы Комиссии НКВД и Прокурора СССР по приказу № 00439).

${ }^{9}$ Охотин Н., Рогинский А. Из истории «немецкой операции» НКВД 1937-1938 гг. Наказанный народ. М.: «Звенья», 1999. С. 49; Ватлин А.Ю. «Ну и нечисть». Немецкая операция НКВД в Москве и Московской области 1936-1941 гг. М.: РОССПЭН. 2012. С. 17.

10 Лубянка. Сталин и Главное управление госбезопасности НКВД... С. 612-617.

${ }^{11}$ Архив УФСБ по Омской области. Ф. 6. Пор. 3142 Л. 50; Ф. 6. Пор. 3419. Л. 71-72.
} 
Этим же протоколом Особого совещания от 28 января 1938 г. были осуждены к высылке из страны еще несколько подданных Германии. Материалы на пятерых подготовило УНКВД по Ленинградской области, еще на 13 человек - УНКВД по Свердловской области. Документы на всех поступили на ОСО после рассмотрения дел Комиссией НКВД и Прокурора СССР, которая, собственно, и вынесла решение о выселении. В приложении к протоколу приложены справки, в которых указывается, что немецкие подданные осуждены по приказу НКВД № 00439 от 25 июля 1937 г., протокол Комиссии НКВД и Прокурора СССР № 168 от 14 января 1938 г. Отметим тот факт, что большинство «альбомных» справок на ОСО шло без ссылок на приказы. Начальник УНКВД Свердловской области Дмитриев в своем рапорте в 3-й отдел ГУГБ НКВД информирует, что отправляет «в 3-х экземплярах альбом справок на 11 арестованных в соответствие с приказом № 00439, в отношении которых следствие закончено» ${ }^{12}$, при этом указывая, что по ним уже «есть резолюция Цесарского» от 25 декабря 1937 г. - «всех выслать за пределы СССР» ${ }^{13}$. Получается, что решение по данным лицам было принято задолго до заседания двойки и уж тем более ОСО. Обычно доминировала практика, когда двойка, а вслед за ней и ОСО, просто утверждали решения, предложенные региональными управлениями. В.Е. Цесарский визировал протоколы Особого совещания как секретарь. Помимо подписи Цесарского, на протоколах имеются подписи председателя ОСО - зам. наркома НКВД М.П. Фриновского и зам. прокурора СССР Г.М. Леплевского.

Осужденные к высылке за границу из Свердловской области проходили не просто как «шпионы», а как «шпионы-диверсанты». Им инкриминировались «поджоги» и «порча оборудования». Среди осужденных оказались отец и двое братьев по фамилии Ленске, выходцы с Украины, работавшие на Ревдинском металлургическом заводе. Обвинение строилось вокруг деятельности инженера-механика Карла Ленске, который с 1929 по 1935 гг. проходил обучение в Германии, где и «был завербован», «вступил в фашистскую партию», а после возвращения в СССР «создал на Ревдинском заводе диверсионную группу для совершения в период войны взрывов и поджогов на оборонных предприятиях» ${ }^{14}$. Помимо «немецких шпионов», в этом деле фигурируют также резиденты «польской и латвийской разведок», их также провели по приказу № 00439. Подобное часто практиковалось, поэтому в рамках «немецкой» операции осуждались не только этнические немцы, но представители других национальностей. Отметим тот факт, что несмотря на проведение так называемых национальных операций, учет национального состава арестованных НКВД ввел только с середины мая 1938 г.

В период Большого террора самой массовой из «национальных» операций стала «польская», реализованная по приказу НКВД 00485 от 11 августа 1937 г. Жертвами ее стали 143810 чел. В итоговой статистике НКВД на середину ноября 1938 г. указывалось, что за границу было выслано всего 13 человек ${ }^{15}$. По протоколам Комиссии прошло 51 человек ${ }^{16}$. Такое соотношение в статистике скорее исключение. В целом, незначительное количество депортированных из страны в рамках этой операции можно объяснить тем обстоятельством, что 5 сентября 1937 г. Политбюро ЦК ВКП(б), расширяя в очередной раз права Особого совещания, разрешило приговаривать перебежчиков из Польши к 10 годам тюрьмы.

Третьей по масштабам репрессий стала так называемая «харбинская» операция, проводившаяся на основании приказа НКВД № 00593 от 20 сентября 1937 г. Массовым репрессиям по этой линии подверглись не только бывшие служащие КВЖД и реэмигранты, но и китайцы ${ }^{17}$, имевшие советское гражданство, подданные Китая, нелегальные мигранты,

\footnotetext{
${ }^{12}$ Архив УФСБ по Омской области. Ф. 6. Пор. 3421. Л. 166.

13 Там же.

${ }^{14}$ Архив УФСБ по Омской области. Ф. 6. Пор. 3421. Л. 181.

15 ЦА ФСБ. Ф. 3. ОП. 5. Д. 1528. Л. 329.

16 Архив УФСБ по Омской области. Ф. 6. (Протоколы Комиссии НКВД и Прокурора СССР по приказу № 00485).

${ }^{17}$ Подробнее см.: Потапова Н.А. Антикитайская акция НКВД СССР периода «большого террора» в
} 
интернированные китайские военнослужащие из Маньчжурии. Китайцев арестовывали по всей стране, но наиболее массово на Дальнем Востоке. Всего по «харбинской» операции репрессировали 49470 человек, в том числе китайцев - более 16 тысяч ${ }^{18}$.

Аресты китайцев сопровождались депортациями. В августе-октябре 1937 г. китайцы вместе с корейцами массово выселялись в Среднюю Азию и Казахстан. 1 февраля 1938 г. Политбюро приняло решение об очистке погранзоны от «антисоветского и неблагонадежного элемента», в том числе иностранцев и иноподданных. 5 марта и 10 июня 1938 г. вышли постановления о депортации китайцев в Казахстан и Синьцзян, проведение которых поручалось НКВД ${ }^{19}$. На реализацию решения Политбюро от 5 марта была направлена директива НКВД № 11161 от 16 мая 1938 г. В разъяснении к ней от 3 июня 1938 г. указывалось, что высылке в Синьцзян подлежат китайцы, заявляющие о своем китайском подданстве, но не имеющие ни китайских, ни советских паспортов. Выехать из страны могли также советские жены китайских подданных (при этом супруги ранее высланных в Казахстан китайских подданных такой возможности не получили). Ссылке в Казахстан подлежали также китаянки китайского подданства. Перевозку китайцев из Дальневосточного края провели организовано в конце мая 1938 г., загрузка эшелонов производилась во Владивостоке. Отправке в Синьцзян подлежали 6189 китайских граждан с семьями $^{20}$, однако вопрос о том, сколько все-таки китайцев пересекло границу остается открытым, поскольку после отправки первого эшелона, в составе которого было 1379 чел., выселение приостановили по распоряжению НКВД.

Новую волну переселения НКВД инициировал после решения Политбюро от 10 июня 1938 г. Хотя в нем и указывалось, что переселение китайцев с Дальнего Востока в Синьцзян может быть только «добровольным», одновременно предписывалось «арестованных китайцев, исключая осужденных и обвиняемых в шпионаже, активной диверсии и терроре, из-под стражи освободить и выселить в Синьцзян, вместе с их семьями и имуществом» ${ }^{21}$. Одновременно власть санкционировала прекращение массовых арестов китайцев. Выселение регламентировала Постановление Политбюро от 10 июня 1938 г. Из тюрем было освобождено 2853 китайца 22 . Отказавшихся от выезда в Синьцзян ожидало насильственное переселение в пределах Дальневосточного края. Есть данные, что в ходе этой волны в Синьцзян было выслано 3173 чел. ${ }^{23}$ Вывоз, как и прежде, шел по железной дороге. Конечной остановкой была станция Аягуз Туркестано-Сибирской железной дороги, выпуск за кордон осуществлялся через контрольно-пропускной пункт Бахты.

В виду проведения массового выселения китайцев за пределы СССР, «китайские» альбомы, отправленные УНКВД по ДВК на Комиссию НКВД и Прокуратуры СССР, скорее всего, были аннулированы летом 1938 г. Особое совещание к началу сентября 1938 г. рассмотрело лишь «остатки» «китайских» альбомов. В ходе заседаний 2 и 5 сентября 1938 г. комиссия НКВД и Прокурора СССР приняла решение о высылке из страны 364 граждан Китая. Самые большие партии прошли по протоколам от 2 сентября за № 524 (70 чел.) и

Дальневосточном крае: механизмы и масштабы репрессии // Проблемы Дальнего Востока. 2018. № 3. С. 156162; Аблажей Н.Н. «Харбинская операция» НКВД в 1937-1938 гг. // Гуманитарные науки в Сибири. 2008 . № 2. C. $80-85$.

${ }^{18}$ Потапова Н.А. Антикитайская акция НКВД СССР... С. 161.

19 Чернолуизкая E.H. Принудительные миграции на советском Дальнем Востоке в 1920-1950-е гг. Владивосток, 2011. С. 363.

${ }^{20}$ Там же. С. 262.

21 Чернолуичкая Е.Н. Вытеснение китайцев с Дальнего Востока и депортация 1938 г. // Проблемы Дальнего Востока. 2008. № 4. С. 133-145.

22 Даџышен В.Г. Политические репрессии и китайцы в CCCP [Электронный pecypc]. URL: http://www. penpolit.ru/papers/detail2.php?ELEMENT_ID $=947$

23 Чернолуиякая Е.Н. Депортация китайцев из Приморья (1938 г.) // Исторический опыт открытия, заселения и освоения Приамурья и Приморья в XVII-XX вв. (к 350-летию начала похода В.Д. Пояркова на Амур): тезисы докладов и сообщений Международной научной конференции. Владивосток, 1993. Вып. 2. С.78-81. 
№ 531 (71 чел.), от 5 сентября за № 541 (44 чел.) и № 553 (37 чел.) ${ }^{24}$. Отметим, что помимо этого, только за два упомянутых сентябрьских дня Комиссия подписала приговоры на 8998 человек, из которых 4125 человек были приговорены к расстрелу ${ }^{25}$.

Массовую высылку иностранцев из страны обеспечила также «иранская» операция НКВД. Хотя «иранская» линия в репрессиях обозначилась одной из первых, аресты и высылки ирано-подданных начались уже в начале 1937 г., в качестве общесоюзной карательной акции «иранская» кампания стартовала только 5 февраля 1938 г. Вопрос о репрессиях в отношении подданных Ирана, представленных в основном выходцами из иранского Южного Азербайджана, обсуждался в верхах неоднократно. Руководитель Азербайджанской ССР М.Дж. Багиров в декабрьском 1936 г. письме И.В. Сталину указывал, что «иранская колония в Азербайджане насчитывает 17746 чел., а вместе с семьями до 67 000, по Баку это число доходит до 11500 , а с семьями до $46000 »{ }^{26}$. Несколько меньшие цифры были озвучены 19 января на заседании Политбюро: «суммарная численность иранцев в СССР - 40 тысяч, иранских подданных - 15 тысяч» ${ }^{27}$.

Отходничество из Персии (Ирана) в Россию было широко распространено как во времена империи, так и в первые полтора десятилетия советской власти. Две третьих от числа сезонных рабочих проживало в Баку, где они работали преимущественно на нефтяных промыслах, в Каспийском пароходстве и на железной дороге. Несмотря на то, что трудовые мигранты из Ирана с начала 1930-х гг. сталкивались в СССР со значительными трудностями, дискриминационная политика шаха Реза Пехлеви в отношении азербайджанцев стимулировала их миграцию в Советский Азербайджан. На фоне резкого ухудшения экономической ситуации в регионе, в 1937 г. СССР ввел запрет на въезд сезонных рабочих из Ирана. Начало массовых репрессий против ирано-подданных совпало с резким ухудшением отношений с Ираном, что было обусловлено расширением контактов этой страны с Германией. 3 января 1938 г. Политбюро ЦК ВКП(б) приняло решение о закрытии четырех иранских консульств в СССР и всех советских диппредставительств в Иране.

Старт депортациям иранских подданных дало постановление СНК СССР от 17 декабря 1936 г. «О выселении контрреволюционных элементов из Азербайджана в Иран и отдаленные районы СССР», что мотивировалось необходимостью «зачистки» приграничных и режимных местностей от «неблагонадежных» элементов. Описание механизма и масштабов кампании содержались в директиве НКВД № 233 от 9 января 1937 г. К выселению из Баку и пограничной зоны Азербайджана было намечено 2500 иранских поданных (среди них - исключенные из ВКП(б), ранее осужденные, перебежчики), а также 700 семей «к.-р. элемента» ${ }^{28}$. Вскоре заместитель наркома внутренних дел Азербайджанской ССР Т.М. Борщев проинформировал Москву, что в Иран уже «выдворено» 1167 человек и намечено к выселению 2878 человек ${ }^{29}$. В литературе встречаются данные, что в 1937 г. было арестовано и выдворено из Советского Азербайджана в Иран 2532 «персидско-подданных», а в 1938 г. планировалось выселить еще 10380 человек $^{30}$.

Усиление репрессий по «иранской» линии было санкционировано Сталиным 17 января 1938 г. Он потребовал от Ежова отчета об арестах «всех иранцев в Баку и Азербайджане». На следующий же день за подписью Ежова в НКВД Азербайджана была направлена

\footnotetext{
${ }^{24}$ Потапова Н.А. Антикитайская акция НКВД СССР... С. 160-161.

${ }^{25}$ Там же.

${ }^{26}$ Мамедова 3.А. Проблема южных азербайджанцев в Советском Азербайджане в 20-30-х гг. ХХ века : автореф. дис. ... д-ра филос. по ист. Баку, 2014. С. 21-22. (Со ссылкой на: АПДУДПАР. Ф. 1. ОП. 88. Д. 515. Л. 4,6$)$.

${ }^{27}$ Сталинские депортации. 1928-1953... С 100.

28 Охотин Н.Г., Рогинский А.Б. «Большой террор»: 1937-1938, Краткая хроника [Электронный ресурс]. URL: http://www.memo.ru/history/y1937/hronika1936_1939/xronika.html

${ }_{29}$ Мамедова 3.А. Проблема южных азербайджанцев в Советском Азербайджане в 20-30-х гг. ХХ века... C. 22.

${ }^{30}$ Там же. С. 23.
} 
шифротелеграмма, в которой ставилась задача немедленно арестовать «всех иранцев иранских подданных и иранцев, не имеющих ни советских, ни иностранных паспортов» ${ }^{31}$. Еще через день, 19 января 1938 г., Политбюро приняло решение об ускоренном принятии советского гражданства подданными Ирана ${ }^{32}$, в соответствии с которым властям Азербайджана давалось указание проинформировать иранцев, желающих остаться в СССР, о необходимости в течение 10 -ти дней оформить советское гражданство ${ }^{33}$. В отношении членов семей репрессированных, имеющих иностранное подданство, было дано распоряжение «либо выдворять при желании в Иран, либо за пределы Азербайджана, в районы по особому указанию» ${ }^{34}$.

29 января 1938 г. на места была спущена директива НКВД СССР № 202 о расширении «иранской» операции на всю территорию СССР. Аресты начались по всей стране, но наиболее активно - в Азербайджане ${ }^{35}$. Спустя два месяца после начала операции только в

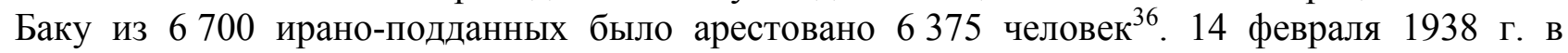
развитие «иранской» директивы на места за подписью М.П. Фриновского было спущено разъяснение о принципах выселения из страны ираноподданных. В директиве указывалось: «1. Арестованные по операции иранско-подданные, в отношении которых нет серьезных улик антисоветской и шпионской деятельности, будут высылаться за пределы Союза - в Иран. 2. Для вынесения решения о высылке представлять на Особое Совещание НКВД альбомы с персональными справками. 3. Предупредить высылаемых, что до отъезда из СССР они имеют право распорядиться принадлежащим им в СССР имуществом - через находящихся на свободе родственников или выдачей доверенностей своим знакомым. Начальникам тюрем - заверять доверенности арестованных иранцев. 4. Разрешить выезд за границу семьям высылаемых независимо от гражданства членов семей при их согласии» ${ }^{37}$.

Данное решение спровоцировало в марте - апреле 1938 г. волну писем с мест на имя В.Е. Цесарского. В них начальники УНКВД обращались с просьбой передать часть персональных справок из региональных альбомов сразу на рассмотрение Особого совещания. Так, начальник УНКВД Рязанской области в служебной записке, сопровождающей «альбомную» справку на ирано-подданного, отмечал, что «справка на предмет выселения (ФИО опущено - Авт.) [...] за пределы СССР была подана согласно телеграммы М.П. Фриновского от 14 февраля 1938 г.», и ввиду того, что «достаточных данных о шпионской деятельности нет», то персональную справку необходимо передать на рассмотрение Особого совещания на предмет вынесения решения о высылке ${ }^{38}$. Следует отметить, что директива НКВД от 14 февраля никаких изменений в порядок подачи документов не вводила. Альбомы, как и прежде, поступали на рассмотрение Комиссии НКВД и Прокурора СССР с сопроводительными справками о количестве арестованных по приказам, либо с указанием линии шпионажа. И только после рассмотрения материалов альбомов двойкой справки на лиц, подлежащих высылке изымались из альбома и отправлялись на рассмотрение ОСО.

В отношении приговоренных к высылке за границу случались пересмотры дел. Ключевым поводом к пересмотру решения о депортации из страны был фактор гражданства. Бывало, что наличие национального паспорта становилось основанием для пересмотра дела

\footnotetext{
${ }^{31}$ Хаустов В., Самуэльсон Л. Сталин, НКВД и репрессии 1936-1938 гг. М.: РОССПЭН, 2010. С. 296.

${ }^{32}$ Сталинские депортации. 1928-1953... С. 100.

${ }^{33}$ РГАСПИ. Ф. 17. ОП. 3. Д. 994.

${ }^{34}$ Сталинские депортации. 1928-1953... С. 99-100.

35 Подробнее: Зейналов Э. «Иранская» операция НКВД: как это было? [Электронный pecypc]. URL: https:// minval.az/news/123648065

${ }^{36}$ Мамедова 3.А. Проблема южных азербайджанцев в Советском Азербайджане в 20-30-х гг. ХХ века... С. 22 (Со ссылкой на: АПДУДПАР. Ф. 1. Оп. 88. Д. 346. Л. 70).

${ }^{37}$ ЦА ФСБ. Ф. 3. ОП. 5. Д. 1528. Л. 329.

${ }^{38}$ Архив УФСБ по Омской области. Ф. 6. Пор. 10519. Л. 75.
} 
осужденного к лагерному сроку и замене ИТЛ на высылку за границу ${ }^{39}$. В случае подтверждения факта наличия советского гражданства дело также могло быть пересмотрено Особым совещанием. Инициатива пересмотра обычно шла из региона, подобное обращение исходило либо от начальника УНКВД, либо от начальника ДТО ГУГБ НКВД той или иной железной дороги. В таких случаях «альбомная» справка направлялась повторно на Особое совещание и сопровождалась запиской следующего содержания: «просим пересмотреть решение по прилагаемой справке с целью изменить это решение, на осуждение для отбытия наказания в ИТЛ как гражданина СССР, а не ирано-подданного» ${ }^{40}$. Ввиду того, что в 1937 г. имело место массовое получение советского гражданства ирано-подданными, в «альбомных» справках встречаются следующие комментарии - «по национальности является иранцем и был иранским подданным до 1937 г. В настоящее время гражданин СССР» ${ }^{41}$. Тех, кто перешел в советское подданство уже после окончания операции, летом - осенью 1939 г., решением Особого совещания выслали с семьями на пять лет в Северный Казахстан.

На примере «иранской» операции хорошо заметна тенденция увеличения случаев пересмотра дел на финальном этапе массовых операций. Подобная практика имела место в отношении 15 иранцев, прошедших по одному из «грузинских» альбомов, в котором числилось 54 человека. 2 июля ирано-подданные были приговоренных к высылке из страны, а 31 августа - осуждены на 10 лет ИТЛ. 31 октября 1938 г. приговор в отношении всех проходящих по этому альбому был отменен Комиссией НКВД и Прокурора СССР, о чем 1 ноября 1938 г. начальник 1-го спецотдела НКВД И.И. Шапиро лично проинформировал наркома внутренних дел Грузии С.А. Гоглидзе ${ }^{42}$. Власть уже пыталась приостановить маховик репрессий. Но только 15 ноября Политбюро принимает решение о приостановке рассмотрения дел, направленных на рассмотрение «троек», военных трибуналов и Военной коллегии Верховного суда СССР в порядке особых приказов. Несмотря на это, даже после нескольких директив НКВД о приостановке репрессий, новый нарком внутренних дел Л.П. Берия был вынужден 22 декабря 1938 г. отправить на места очередную телеграмму, где предписывалось считать утратившими силу все приговоры внесудебных органов (тройки, двойка, Особое совещание), если они не были приведены в исполнение или не были объявлены осужденным до 17 ноября ${ }^{43}$. Необходимо, однако, заметить, что арестованные по иранской операции и освобожденные из тюрем все-таки были репрессированы позже. В августе - сентябре 1939 г. их сослали как «социально-опасных» в Казахстан по решению все того же Особого совещания.

В справке о количестве дел, рассмотренных центром и особыми тройками НКВД (УНКВД) по национальным операциям за период с 25 августа 1937 г. по 15 ноября 1938 г. указывается, что по «иранской» операции было репрессировано 13550 человек ${ }^{44}$. При этом через Комиссию прошло 2350 человек, через Особые тройки - 2727 человек ${ }^{45}$. Попытаемся выяснить, чем обусловлен такой разрыв в статистике. В отчетных данных НКВД количество высланных из страны по «иранской» операции оценено в 8174 чел.; в комментариях указано, что «7 884 чел. высланы за пределы СССР НКВД Азербайджанской ССР согласно приказа НКВД № 0023» ${ }^{46}$. Вряд ли в итоговую статистику могла закрасться техническая ошибка (хотя приказ с таким номером нам не известен). Разница между итоговыми данными по

\footnotetext{
${ }^{39}$ Архив УФСБ по Омской области. Ф. 6. Пор. 7422. Л. 95

40 Там же. Пор. 7421. Л. 25.

41 Там же. Л. 24.

42 Архив УФСБ по Омской области. Ф. 6. Пор. 10525, Л. 63-64, 66, 72.

43 Трагедия советской деревни. Коллективизация и раскулачивание. Документы и материалы. Москва РОССПЭН, 2006. Т. 5. 1937-1939. Кн. 2. 1938-1939. С. 306-307. (Со ссылкой на: РГАСПИ. Ф. 17. Оп. 162. Д. 24. Л. 62).

${ }^{44}$ ЦА ФСБ. Ф. 3. Оп. 5. Д. 1528. Л. 329.

45 Архив УФСБ по Омской области. Ф. 6. (Протоколы Комиссии НКВД и Прокурора СССР по директиве № 202).

${ }^{46}$ ЦА ФСБ. Ф. 3. ОП. 5. Д. 1528. Л. 329.
} 
количеству высланных из страны составляет 290 человек. При обработке материалов Комиссии получается, что приговоренных к высылке из страны оказалось 289 человек. Другими словами, что через двойку и ОСО прошло только 3,7 \% от числа лиц, попавших в отчетную статистику НКВД как высланные из страны в рамках «иранской» операции. Наибольшее количество высланных обеспечили Ростовская область (67 чел.), ДТО ж.д. им. Орджоникидзе (41 чел.), Грузинская ССР (25 чел.). Сталинградская (21 чел.) и Ленинградская обл. (18 чел.) $)^{47}$. Депортируемым из страны чаще всего инкриминировался шпионаж, связи с консульствами, «незаконное» приобретение иранского паспорта, агитация в пользу эмиграции в Иран и контрабанда. Крайне любопытным является информация, согласно которой некоторым ирано-подданным еще в 1935 г. было отказано в получении советского вида на жительство и предложено «выехать в Иран», но многие от «выезда уклонились», сменили место жительства и скрывались вплоть до ареста. Таких фигурантов за границу не отправляли.

Анализ «альбомных» справок позволяет утверждать, что среди приговоренных к высылке из страны оказалось немало «персов», ассирийцев и армян. У большинства имелись национальные паспорта, выданные преимущественно в 1933-1934 гг. иранскими посольством в Москве и консульствами в Ростове-на-Дону и Баку. Именно «консульский след» красной нитью проходит по многим «альбомным» справкам. Например, приговоренный к депортации из СССР армянин Аракельянц Арапет Мамейлович 1903 г.р., уроженец г. Хой, живя в Астрахани, получил загранпаспорт в Баку 20 сентября 1934 г. В «альбомной» справке указывалось, что «парикмахер Аракельянц тесно связан с иранским консульством. По указанию сотрудника иранского консульства Асана (выдворен в Иран) проводил контрреволюционную агитацию» ${ }^{48}$. Следующим в протоколе ОСО из тех, кто был приговорен к высылке из страны, оказался Егиш Данильян 1918 г.р. Ему также вменялась в вину «связь с иранским консульством», помимо этого, инкриминировалось то, что он, «будучи советским гражданином, [...] получил посредством дачи взятки иностранный паспорт» с целью «избежать службы в Красной Армии», при этом в справке он проходил как «ирано-поданный». Указывалось также, что его национальный паспорт находится в иранском посольстве Москве на «предмет обмена» ${ }^{49}$.

Материалы внесудебных инстанций не позволяют судить о том, как сложились судьбы этих людей: оказались ли они в Иране, в лагере, в ссылке в Казахстане, были расстреляны или погибли в заключении? Хотя бы отчасти прояснить картину позволяют следственные дела. Приведем некоторые свидетельства на примере лиц ассирийской национальности, которых как «иранских шпионов» в рамках «иранской» же операции приговорили к высылке из страны. Осужденный к выдворению из СССР постановлением ОСО от 28 марта 1938 г. Георгий Аблаган, 1920 г.р., умер 3 июля 1938 г. в тюрьме г. Таганрога. Осужденный 28 сентября ОСО к высылке из страны Шауль Аблакатов расстрелян в Ростове на основании решения Комиссии от 5 сентября, а его жена и трое детей высланы в Иран. Владимир Ананьев (ассириец), житель Москвы, осужден ОСО 14 мая 1938 г. к депортации из страны; выдворен из СССР в Иран 5 октября 1938 г. через КПП г. Баку. Давид Бадалов из Ленинграда по решению ОСО от 14 сентября выслан «за пределы СССР»; жена и дети остались в СССР (жена до самой смерти была уверена, что ее мужа расстреляли). Иван Вардаев, житель Калининской области, осужден ОСО 22 сентября к высылке и выдворен с женой в Иран ${ }^{50}$. Перечень людских трагедий можно продолжать и продолжать.

Возвращаясь к вопросу о количестве высланных по «иранской» линии, можно утверждать, что количество депортированных из страны оказалось существенно больше, чем указано в

${ }^{47}$ Архив УФСБ по Омской области. Ф. 6. (Протоколы Комиссии НКВД и Прокурора СССР по директиве № 202).

48 Архив УФСБ по Омской области. Ф. 6. Пор. 3485 (1). Л. 45.

49 Там же. Л. 46.

${ }^{50}$ Мартиролог ассирийцев СССР (1920-1950-е гг.) / авт.-сост.: игумен Стефан (Садо). СПб: НП-Принт, 2017. C. 56, 57, 109-110, 141-142, 223. 
отчетной статистике НКВД на момент окончания массовых операций. Об этом наглядно говорят отчеты НКВД Азербайджанской ССР. Так, из отчета от 5 апреля 1938 г. следует, что из г. Баку в Иран было выслано 3740 чел., из них глав семей - 1250 , женщин - 690, детей $1800^{51}$. Статданные на 12 сентября 1938 г. дают совершенно иную картину: депортировано в Иран 32302 чел., из них 10868 глав семей, 21434 членов семей ${ }^{52}$. Уже после окончания массовых операций, 27 декабря 1938 г. Политбюро ЦК ВКП(б) приняло решение выселять из СССР «всех арестованных ирано-подданных, которые являются физически здоровыми», вместе с их семьями. На 1 января 1939 г. под арестом оставались 1500 иранцев, из них лишь 711 были иранскими гражданами ${ }^{53}$. Логично предположить, что этот контингент если и выслали, то не в Иран, а в Казахстан.

Помимо «польской», «немецкой», «харбинской», «иранской» операций, из страны высылали еще по шести «национальным» линиям, реализованным в общесоюзном масштабе. Статистика по ним следующая: «смешанные» - 37 человек, «греческая» - 28, «румынская»четыре, «латышская» - три, «финская» - два, «афганская»- один человек ${ }^{54}$. Получается, что из страны не высылали только в рамках «эстонской» операции.

Так называемая «смешанная» операция стала комбинированной карательной акцией, объединившей несколько «национальных» линий. Хотя исследователям до сих пор не удалось обнаружить соответствующий оперативный приказ, специалисты, работавшие с материалами внесудебных инстанций, убеждены, что ее формат («альбомный» порядок осуждения) полностью аналогичен другим «национальным» операциям. Вполне возможно, что решение о выделении особой линии («разные») было принято на уровне Комиссии НКВД и Прокурора СССР, когда еще не все «национальные» операции были «запущены», что давало свободу маневра при распределении контингента. Однако эту линию не свернули и после того, когда такие возможности появились. Территориальные органы НКВД формировали «альбомные» справки, руководствуясь принципом разбивки контингента по приказам или с указанием конкретного «направления» шпионажа. Часть контингента Центр «пропускал» в порядке «национальных» приказов, а часть «националов» переводили в категорию «разные», иногда конкретизируя линию шпионажа, либо огульно обвиняя «в шпионской и диверсионной деятельности в пользу иностранных государств», без уточнения, каких именно. «Первый «смешанный» протокол был подписан двойкой 8 января 1938 г. К началу сентября 1938 г. в рамках этой линии было осуждено около 8,3 тыс. человек. Более 6 тыс. из них, проведенные Комиссией по «смешанной» линии (это с учетом того, что первые протоколы не сохранились), до ареста проживали в РСФСР. Перечень из 37 человек, приговоренных к высылке из страны, включает выходцев из 14-ти российских регионов (35 человек) и Узбекской ССР (2 человека). В частности, протоколы с «разными» скомпоновали за счет списков, предоставленных Управлениями НКВД по Ленинградской (5 человек), Свердловской (5 человек), Ивановской (4 человека) областей и Мордовской АССР (4 человека). Еще пятерых добавили из списков УНКВД дорожно-транспортных отделов (ДТО) Сталинградской, Московско-Киевской и Юго-Восточной железных дорог. Это при том, что именно ДТО всегда сопровождали свои справки обязательным указанием на тот или иной оперативный приказ НКВД.

Среди осужденных по «смешанной» линии можно встретить подданных Австрии, Чехословакии, Болгарии, Югославии, Китая, Ирана и других стран; большинство составили иранские и китайские подданные. При этом вполне вписывавшиеся в формат «иранской» операции лица, приговоренные к высылке из страны, оказались проведены не по «иранским», а по «смешанным» протоколам. Однако в таких случаях, при указании «окраса»

51 Мамедова 3.А. Проблема южных азербайджанцев в Советском Азербайджане в 20-30-х гг. ХХ века... С. 21 (Со ссылкой на: ЦГА ППОД АР. Ф. 1. Оп. 88. Д. 346. Л. 70).

52 Там же. (Со ссылкой на: АМНБ АР. ПС № 12358. Т. 5).

53 Подробнее: Зейналов Э. «Иранская» операция НКВД: как это было? [Электронный pecypc]. URL: https:// minval.az/news/123648065

${ }^{54}$ ЦА ФСБ. Ф. 3. ОП. 5. Д. 1528. Л. 329. 
подследственных, нередко указывалась, что это «контрреволюционный элемент» или агенты, но уже тех государств, граждане которых не проходили по оперативным приказам НКВД. Так, пятеро ирано-подданных, материалы на которых предоставило УНКВД по Свердловской области, в Комиссии походили не как «иранские», а как «английские шпионы» ${ }^{55}$.

Приведем конкретный пример: к высылке из страны по «смешанной» линии был приговорен итальянец Галини Михаил Иванович (Gallini Michele, Галлини Микеле Джованнович), до ареста работавший пианистом в ресторане в г. Саранске. В справке на него, подготовленной НКВД Мордовской ССР, указывалось, что он «завербован в 1923 г. агентом (ФИО опущено - Авт.) в момент его приезда в г. Саранск на гастроли». Далее сообщалось, что в 1925 г. он организовал крушение товарного поезда на Ленинской железной дороге; в 1926 г. подготовил новую диверсию (разобрал пути), однако это было вовремя обнаружено. Утверждалось, что «за свою диверсионную деятельность получил вознаграждение от (ФИО опущено - Авт.) в объеме 800 руб.». В 1937 г., но уже по поручению другого агента, «собирал шпионские материалы, касающиеся военной промышленности, получив вознаграждение в 1500 руб.» ${ }^{56}$. Решение Комиссии датируется 22 мая, а решение ОСО - 10 июня 1938 г.

Еще один характерный пример: Комиссия провела по «смешанной» операции и австрийского подданного Пабста Франца Францевича 1898 г.р. «Альбомная» справка подготовлена УНКВД по Ивановской области, предлагалось выселение из страны. В базе данных «Мемориала» (Открытый список) персональная информация о Пабсте основана на данных, приведенных в «Книги памяти жертв политических репрессий Ивановской области». Сведения минимальны, данных о том, как именно был репрессирован этот человек, вообще нет $^{57}$. Из протоколов Комиссии следует, что первое решение по его делу было принято 20 февраля 1938 г., а уже 22 февраля решение приняло ОСО. Однако 13 октября 1938 г. решение о высылке было аннулировано, с указанием на то, что «австрийский гражданин Пабст национального паспорта не имеет, проживал в СССР по виду на жительство для иностранцев без предъявления нацпаспорта». Было дано указание рассмотреть это дело на месте, руководствуясь приказом № 00606 от 17 октября 1938 г. и циркуляром № 189 от 29 октября 1938 г. ${ }^{58}$ На практике это означало, что решение по данному делу приняла «особая тройка» и это была скорей всего уже не депортация, а лагерный срок (поскольку, напомним, данная внесудебная инстанция не имела права на высылку из страны). Данный пример наглядно показывает, как материалы внесудебных инстанций позволяют расширить информацию о репрессированном.

«Греческую» операцию провели на основании директивы № 50215 НКВД СССР от 11 декабря 1937 г. ${ }^{59}$ Основными районами проведения стали Украина, Грузия и Причерноморье. Согласно итоговой статистике НКВД, ее жертвами стали 12867 человек, из которых 10545 человек было расстреляно ${ }^{60}$ (по протоколам Комиссии прошло 11038 человек $\left.{ }^{61}\right)$. В итоговой справке указывается, что количество высланных из страны составило 28 человек, а по протоколам двойки числится 27 человек. По 16 человек выслали Грузия и Крым, 8 человек - Краснодарский край и 7 человек - Одесская область.

Минимальное количество высланных зафиксировано в рамках «афганской» операции. Всего по этой линии репрессировали 1775 чел. Мирасмаилов Абдул Хамит 1885 г.p.,

\footnotetext{
55 Архив УФСБ по Омской области. Ф. 6. Пор. 3608 (т. 2). Л. 118, 172.

56 Там же. Пор. 3525 (т. 1). Л. 147.

${ }^{57}$ Пабст Франц Францевич [Электронный pecypc]. URL: https://ru.openlist.wiki/Пабст_Франц_ Францевич_(1898); [Электронный ресурс]: URL: http://base.memo.ru/person/show/1293035

${ }^{58}$ Архив УФСБ по Омской области. Ф. 6. Пор. 10517. Л. 22-24.

59 Джуха И.Г. Греческая операция. История репрессий против греков в СССР. СПб.: Алетейя, 2006. С. 123.

${ }^{60}$ ЦА ФСБ. Ф. 3. Оп. 5. Д. 1528. Л. 329.

${ }^{61}$ Архив УФСБ по Омской области. Ф. 6. (Протоколы Комиссии НКВД и Прокурора СССР по директиве № 50215).
} 
работал курьером-переводчиком афганского консульства в г. Мары Таджикской ССР, стал единственным высланным из страны рядовым гражданином по «афганскому» приказу НКВД № 326 от 16 февраля 1938 г. Помимо него, из страны были выдворены консул и секретарь афганского консульства в г. Мерв. Вопрос о высылке афганского консула в Мерве, после обращения секретаря ЦК КП(б) Туркмении, был решен лично Сталиным, который одобрил его высылку в «дипломатическом порядке» ${ }^{62}$.

Суммарно, согласно итоговой статистике НКВД за период с 25 августа 1937 г. и по 15 ноября 1938 г., число депортированных из страны по «национальным» операциям составило 9212 чел. $^{63}$ Наибольшее количество высланных за пределы страны дали «иранская» (ок. 89 \%), «немецкая» (ок. $6 \%$ ) и «харбинская» (ок. 4 \%) операции НКВД. Внесудебные инстанции (Комиссия НКВД и Прокурора СССР, Особое совещание) приговорило к высылке 1350 чел. В итоговую статистику НКВД по количеству репрессированных в рамках массовых операций оказались лишь частично включены высланные по решениям Центра, в том числе члены их семей. Имеющиеся фрагментарные данные о суммарном количестве высланных из страны позволяют утверждать, что таковых оказалось не менее 35 тысяч. Помимо этого, «иноподданные» и «бесподданные» стали жертвами и других видов наказаний, массовый характер которых обеспечили так называемые национальные операции НКВД. Насильственные депортации из страны, относящиеся к периоду 1937-1938 гг., представляли собой лишь одну из разновидностей политических репрессий, от которых пострадала примерно треть проживавших в стране иностранцев. Доминирующим критерием для преследования был не только иногражданский статус, но и этническая принадлежность.

\section{Литература}

Аблажей Н.Н. «Харбинская операция» НКВД в 1937-1938 гг. // Гуманитарные науки в Сибири. 2008. № 2. С. 80-85.

Джуха И.Г. Греческая операция. История репрессий против греков в СССР. СПб.: Алетейя, 2006. 416 с.

Журавлев С.В. Иностранцы в Советской России в 1920-1930-е гг.: источники и методы социально-исторического исследования : автореф. дис. ... д-ра ист. наук. М., 2000. 40 с.

Зейналов Э. «Иранская» операция НКВД: как это было? [Электронный ресурс]. URL: https://minval.az/news/123648065

Лор Э. Российское гражданство: от империи к Советскому Союзу / Пер. с англ. M. Семиколенных. М.: Новое литературное обозрение. 2017. (Серия HISTORYA ROSSICA). $344 \mathrm{c}$.

Лубянка. Сталин и Главное управление госбезопасности НКВД. Архив Сталина. Документы высших органов партийной и государственной власти. 1937-1938. М.: МФД, 2004. $737 \mathrm{c}$.

Мамедова 3.А. Проблема южных азербайджанцев в Советском Азербайджане в 20-30-х гг. XX века : автореф. дис. ... д-ра филос. по ист. Баку, 2014. 27 с.

Мартиролог ассирийцев СССР (1920-1950-е гг.) / авт.-сост.: игумен Стефан (Садо). СПб: НП-Принт, 2017. 742 с.

Охотин Н., Рогинский А. Из истории «немецкой операции» НКВД 1937-1938 гг. // Наказанный народ. Репрессии против российских немцев. М.: Звенья, 1999. С. 35-75.

Охотин Н.Г., Рогинский А.Б. «Большой террор»: 1937-1938, Краткая хроника [Электронный ресурc]. URL: http://www.memo.ru/history/y1937/hronika1936 1939/xronika.html

Петров Н.В., Рогинский А.Б. Польская операция НКВД 1937-1938 гг. // Репрессии против поляков и польских граждан. М.: Звенья, 1997. С. 22-43.

${ }^{62}$ Хаустов В., Самуэльсон Л. Сталин, НКВД и репрессии 1936-1938 гг. М.: РОССПЭН, 2010. С. 295.

${ }^{63}$ ЦА ФСБ. Ф. 3. Оп. 5. Д. 1528. Л. 329. 
Потапова Н.A. Антикитайская карательная акция НКВД СССР периода Большого террора в Дальневосточном крае: механизмы и масштабы репрессий // Проблемы Дальнего Востока. 2018. № 3. С. 156-162.

Трагедия советской деревни. Коллективизация и раскулачивание. Документы и материалы Том 5. 1937-1939. Книга 2. 1938-1939. Москва РОССПЭН, 2006.

Хаустов В., Самуэльсон Л. Сталин, НКВД и репрессии 1936-1938 гг. М.: РОССПЭН, 2010. $432 \mathrm{c}$.

Чернолуичкая E.H. Депортация китайцев из Приморья (1938 г.) // Исторический опыт открытия, заселения и освоения Приамурья и Приморья в XVII-XX вв. (к 350-летию начала похода В.Д. Пояркова на Амур): тезисы докладов и сообщений Международной научной конференции. Владивосток, 1993. Вып. 2. С. 78-81.

Чернолуикая Е.Н. Вытеснение китайцев с Дальнего Востока и депортация 1938 г. // Проблемы Дальнего Востока. 2008. № 4. С. 133-145.

\section{References}

Ablazhey N.N. "Kharbinskaya operatsiia" NKVD v 1937-1938 [The "Harbin operation" of NKVD, 1937-1938] // Gumanitarnye nauki v Sibiri. 2008. № 2. S. 80-85. (in Russ.)

Chernolutskaya E.N. Deportatsiia kitaytsev iz Primoria (1938 g.) [Deportation of the Chinese from Primorie] // Istoricheskiy opyt otkrytiia, zaseleniia i osvoeniia Priamuria i Primoria v XVIIXX vv. (k 350-letiu nachala pokhoda V.D. Poyarkova na Amur): tezisy dokladov i soobshcheniy Mezhdunarodnoy nauchnoy konferentsii. Vladivostok, 1993. Vyp. 2. S. 78-81. (in Russ.)

Chernolutskaya E.N. Vytesnenie kitaytsev s Dalnego Vostoka i deportatsiia 1938 g. [Expulsion of Chinese from the Far East and deportation of 1938] // Problemy Dalnego Vostoka. 2008. № 4. S. 133-145. (in Russ.)

Dzhukha I.G. Grecheskaia operatsiia. Istoriia repressiy protiv grekov v SSSR [The Greek operation. The history of repressions against Greeks in the USSR]. St. Petersburg, 2006. 416 s. (in Russ)

Khaustov V., Samuehlson L. Stalin, NKVD i repressii 1936-1938. [Stalin, NKVD and repressions of 1936-1938] Moscow, 2010. 432 s. (in Russ)

Lor E.H. Rossiiskoe grazhdanstvo: ot imperii k Sovetskomu Soyuzu [Russian citizenship: from Empire to the Soviet Union] / Per. c angl. M. Semikolennykh. M.: Novoe literaturnoe obozrenie. 2017. (Seriya HISTORYA ROSSICA). 344 s. (in Russ)

Lubyanka. Stalin i Glavnoe upravlenie gosbezopasnosti NKVD. Arkhiv Stalina. Dokumenty vysshikh organov partiynoy i gosudarstvennoy vlasti. 1937-1938. [Lubianka, Stalin and NKVD Chief Department of the State Security. The Stalin's Archive. Documents of the highest bodies of the party and state authorities. 1937-1938] M.: MFD, 2004. (in Russ)

Mamedova Z.A. Problema yuzhnykh azerbaydzhantsev v Sovetskom Azerbaidzhane v 20-30-h gg. XX veka [The problem of Southern Azerbaijan people in the Soviet Azerbaijan in 1920s 1930s]: avtoref. dis. ... d-ra filosofii po istorii. Baku, 2014. (in Russ)

Martirolog assiriytsev SSSR (1920-1950-e gg.) [The Martyrology of Assyrians in the USSR (1920s -1950s)] / avt.-sost.: igumen Stefan (Sado). SPb: NP-Print, 2017. (in Russ)

Okhotin N., Roginskii A. Iz istorii "nemetskoy operatsii" NKVD 1937-1938 gg. [From the history of the "German operation" of NKVD, 1937-1938] // Nakazannyy narod. M., 1999. (in Russ)

Okhotin N.G., Roginskii A.B. "Bolshoy terror": 1937-1938, Kratkaia khronika [The "Big Terror": 1937-1938, A short Chronicle] [Elektronnyi resurs]. URL: http://www.memo.ru/history/y1937/hronika1936_1939/xronika.html

Petrov N.V., Roginskii A.B. Polskaia operatsiia NKVD 1937-1938 [The Polish operation of NKVD, 1937-1938] // Repressii protiv poliakov i polskikh grazhdan. Moscow, 1997. S. 22-43. (in Russ)

Potapova N.A. Antikitayskaya karatelnaya aktsiya NKVD SSSR perioda Bolshogo terrora v Dalnevostochnom krae: mekhanizmy i masshtaby repressiy [Anti-Chinese punitive action of NKVD 
in the Far-Eastern region: mechanisms and scales of repressions] // Problemy Dalnego Vostoka. 2018. № 3. S. 156-162. (in Russ)

Tragediia sovetskoy derevni. Kollektivizatsiia i raskulachivanie. Dokumenty i materialy [The tragedy of the Soviet village. Collectivization and dispossession. Documents and materials.] Tom 5. 1937-1939. Kniga 2. 1938-1939. Moskva ROSSPEHN, 2006. (in Russ)

Zeinalov E.H. "Iranskaya" operatsiya NKVD: kak eto bylo? [The "Iran" operation of NKVD: how was it?] [Elektronnyy resurs]. URL: https://minval.az/news/123648065 (in Russ)

Zhuravlev S.V. Inostrantsy v Sovetskoy Rossii v 1920-1930-e gg.: istochniki i metody sotsialnoistoricheskogo issledovaniia [Foreigners in Soviet Russia in 1920s - 1930s: sources and methods of research from the perspective of social history]: avtoref. dis. ... d-ra ist. nauk. M., 2000. (in Russ)

Статья поступила в редакичию 30.11.2018 2. 